\title{
DISCOURSE ANALYSIS ON THE STATEMENT OF THE MINISTER OF RELIGIOUS AFFAIRS CONCERNING "GOOD-LOOKING RADICALISM" AGAINST STATE CIVIL APPARATUS
}

\author{
Fania Zakiyah Ulfa1, Ida Fitria Cahyani' ${ }^{2}$, Rozaqul Arif ${ }^{3}$ \\ 1,2Sunan Ampel State Islamic University Surabaya \\ 1faniazakiyah48@gmail.com, 2idafitia30@gmail.com, ${ }^{3}$ rozaqul@uinsby.ac.id
}

\begin{abstract}
This study aims to describe the discourse of the Minister of Religion's statement regarding good-looking radicalism among the State Civil Apparatus. This study uses a descriptive qualitative method with van Djik's critical discourse analysis. The data collection uses documentary techniques from Youtube video webinars and a number of journals. The macrostructure shows that there are strategies that can be done to ward off the entry of radical ideology in ASN. The superstructure shows the process of radicalism agents entering through educational institutions and houses of worship with an attractive appearance to deceive the public. The microstructure analysis shows that this statement of good-looking radicalism has generated polemic in society because it is subjective, that is, it cannot be generalized based on one case. The result of this study shows that some people think that the Minister of Religion agrees with the good-looking radicalism movement. The communicator is the Minister, namely as a messenger to ward off radicalism agents by being careful in selecting ASN. The Minister has access to convey messages to the public to be aware of the entry of radical-minded people into mosques, which usually starts from people who are goodlooking, speak Arabic well, and have sufficient religious knowledge.
\end{abstract}

Keywords: Radicalism; good-Looking; statement of the Minister of Religion; State Civil Apparatus.

\begin{abstract}
Abstrak: Kajian ini bertujuan untuk mendeskripsikan wacana pernyataan Menteri Agama tentang radikalisme good-looking di kalangan Aparatur Sipil Negara. Kajian ini menggunakan metode kualitatif deskriptif dengan analisis wacana kritis van Djik. Pengumpulan datanya menggunakan teknik dokumenter dari video Youtube webinar dan sejumlah jurnal. Struktur makro menunjukkan adanya strategi yang dapat dilakukan untuk menangkal masuknya paham radikal pada ASN. Superstrukturnya menunjukkan proses masuknya agen radikalisme melalui Lembaga Pendidikan maupun rumah ibadah dengan penampilan yang menarik untuk mengelabuhi masyarakat. Analisis struktur mikro menunjukkan, bahwa pernyataan radikalisme good-looking ini menuai polemik di masyarakat karena subjektif, yakni tidak dapat digeneralisasi berdasarkan satu kasus. Hasil kajian ini adalah beberapa masyarakat beranggapan bahwa Menteri Agama menyetujui adanya gerakan radikalisme good-looking. Komunikatornya ialah Menteri Agama, yakni sebagai penyampai pesan untuk menangkal agen radikalisme dengan cara berhati-hati dalam seleksi ASN. Menteri Agama mempunyai akses dalam penyampaian pesan kepada masyarakat untuk mewaspadai masuknya orangorang yang berpaham radikal ke masjid, yang biasanya dimulai dari orang-orang yang goodlooking, berbahasa Arab yang baik, dan pengetahuan agama cukup.
\end{abstract}

Kata Kunci: Radikalisme; good-looking; pernyataan Menteri Agama; Aparatur Sipil Negara.

\section{A. Introduction}

The current radicalism phenomenon is an intriguing phenomenon in some circles and has become increasingly public booming as a result of the massive radical movement in Indonesia that has been characterized by new sects, sects and groups in the name of Islam. ${ }^{1}$ The advent of radicalism is a result of widespread injustice in society. These conditions may be due to countries

1 Muhammad Khomsun Sholeh, Menangkal Masuknya Paham Radikalisme pada Masyarakat Desa (Temanggung: Desa Pustaka Indonesia, 2019), 6. 
as well as other groups of people who understand and believe differently. The wronged party then resisted. ${ }^{2}$ This lack of knowledge about the nature of religion and the lack of the ability to understand and know its intentions are also the cause of such extremes. ${ }^{3}$

One recent social media phenomenon is the "good-looking" that is now an issue among people. As if they had a good-looking face or an appearance was a problem. To make matters worse, good-looking is to be associated with a single sensitive word in society's ears which is radical. Reporting from the portal MENPAN-RB (The Ministry of State-Supporting Personnel and Bureaucratic) reform says that the prevalence of its key radicalism in civil apparatus is stopping the government, showing its full power by creating task force and launching a complaint to deal with violation and reporting that acts against or create hate speech.

The term good-looking began to be addressed when a few weeks ago at the launch of a radical state civil apparatus no application held by the ministry of PAN-RB (the Ministry of StateSupporting Personnel and Bureaucratic). Fachrul Razi, religious minister Fachrul Razi, observes that "through their good-looking entry or entry patterns, good Arabic possession, hafidz entered a community such as the mosque and eventually affected friends or people in the congregation." Finally, this good-looking term became viral. More and more young people are using the term good-looking to relax or even consider good-looking to be another radical term, which goodlooking does not just point to radicalism. It is necessary for understanding to communities, especially young people, that radicalism can arise anywhere. It requires early protection and understanding of society not to be lured into an unfamiliar position The truth. Communities are less tolerant of prejudice and prejudice than in the research world. Individuals with certain characteristics cannot be dismissed as terrorists or radicalists.

There is no correlation between good-looking and radicalism. Literally, the term goodlooking comes from English and this radical term comes from Latin. Good means good, charming, good, and looking means looks. Good-looking means an interesting, good, and good looks. Whereas radical basis is said to be radic, which means root or source, so the radical term has an extreme, fanatical, revolutionary, fundamental meaning. Actually, good-looking is what and how, can't measure it. When something cannot be measured, it becomes biased, and when it cannot establish a particular standard, it will be subjective. When the matter is discussed is subjective, it cannot be worth it. So, there's no certain standard over good-looking. The good-looking word cannot generalize all things based on one case let alone subjective standards.

The purpose of this research is to learning about discourse of the Minister of Religious Affairs of good-looking radicalism among state civil apparatus by a descriptive and critical discourse analysis of Van Dijk for its meaning.

\section{B. Literature Review}

\section{Discourse Analysis}

The term discourse which comes from Latin discursus, is used in both a limited and broad sense. In a limited way, the term refers to rules and customs that underlie the use of language in both oral and written communication. More broadly, the discourse term refers to the language in action as well as the patterns that characterize the kinds of language in action. In the contemporary big dictionary, there are three meanings. First, conversation, speech, and speech. Second, an entire speech or conversation that is a unified thing. Third, the largest, fully operational language unit that is the realization of a complete made-up form, such as the novels, books, and articles of the many discourses analyses that were introduced and developed by some experts, the Van Dijk model was the most widely used one. The critical narrative analysis of Van Dijk's model is not only textual, but it also sees how the social structures, dominance and power groups that exist in society, and how cognition or consciousness that shapes and influences the text that is analyzed.

\footnotetext{
2 Ibid, 9.

${ }^{3}$ Yusuf Qadhawi, Islam Radikal (Solo: PT Era Adicitra Intermedia, 2007), 61.
} 
Van Dijk describes the discourse in three dimensions or buildings: text, social cognition, and social context.

The essence of Van Dijk's theory of analysis is to merge these three dimensions of discourse into one unified analysis. To the dimensions of the text examined how the textual structure and the discourse strategy are used to emphasize a particular theme. At a level of social cognition is studied by the production of news text, which involves individual cognition from journalists or editors. Whereas the third aspect studying the structure is developing in society for a problem that affects journalists or editors' cognition. ${ }^{4}$

\section{Radicalism}

\section{a. The Mean of Radical}

According to Homby, words radical is defined as extreme, fanatical, revolutionary, ultra and fundamental attitudes or views. Radicalism must not appear in the appearance of physical violence but can materialize ideologies of thought, massive campaigns and demonstrations of opposing attitudes and wish to change the mainstream. It can be classified as radical. ${ }^{5}$

Radicalism is from the Latin, radix, which means "root." It is the idea of great changes and piracy to achieve progress. In a social science perspective, radicalism is closely related to an attitude or position that craves a change to the status quo by replacing it with something entirely new and different. Radicalism is a response to the ongoing conditions that arise in the form of evaluation, denial, or even resistance to ideas, assumptions, institutions, or values.

Radicalism, simply put, is a thinking or attitude characterized by four elements at the same time: first, intolerance and a lack of respect for the opinions or beliefs of others. Second, it is fanatical, one that involves self-justifying and blaming others. Third, the exclusive attitude of reclusion and trying to differ from the customs of the crowd. Fourth, the revolutionary tendency to use violence in achieving goals.

According to azyumardi azra, radicalism is an extreme form of revivalism. Revivalism is a more intent-oriented sectarian intensified, with the sense that application of a trust is applied only to oneself. As for the outgoing form of radicalism (oriented), or sometimes in the application it tended to use a common form of violence called fundamentalism. They do much to give common people insight into radicalism. Start delivery in a hidden way until it openly claims to encourage radicalism. Among the examples of good looking radicalism that occurred was Gus Nur, who insulted the Nahdlhatul Cleric, Nikita Mirzani, and one ustadh called "lonte", and many others. ${ }^{6}$

\section{b. Radical in Islam}

Contemporary radicalists claim their beliefs and actions are based on religion, but it is important to understand that religion does not teach radicalism. Radicalism is, in a religious sense, a highly religious trait that results in its violent adherence to different views to conform to theirs. Radicalism among Islamists is often discouraged by narrow religious norms, depression, greatness, psychosocial insecurity, and local and global injustice.

Religion does teach radical understanding and belief in a deep sense down to its roots, but religion does not teach radicalism such as current precursor to negative; view belief, understanding, and the way religion is most right and others wrong, even possibly, uphold belief and understanding and violent means even commit terror (terrorism), and allow fearful killing. ${ }^{7}$

\footnotetext{
${ }^{4}$ Nurul Musyafa'ah, “Analisis Wacana Kritis Model Teun A. van Dijk (Siswa Berprestasi jadi Pembunuh), Jurnal Program Studi PGMI 4, no. 2 (2017): 204-205.

${ }^{5}$ Sholeh, Menangkal Masuknya Paham Radikalisme pada Masyarakat Desa, 6-7.

6 Thohir Yuli Kusmanto, Moh. Fauzi, M. Mukhsin Jamil, "Dialektika Radikalisme dan Anti Radikalisme di Pesantren," Jurnal Walisongo" 23, no. 1 (2015): 29,

https://journal.walisongo.ac.id/index.php/walisongo/article/view/221/202

${ }^{7}$ Sholeh, Menangkal Masuknya Paham Radikalisme pada Masyarakat Desa, 6-7.
} 
Basically, it needs to be differentiated between radicals, radicalization. According to $\mathrm{KH}$. Hasyim Muzadi (Chairman PBNU and Carhoder Al-Hikam), who was met during a national seminar of "Religious Radicalization by the Role of Muballigh in Central Java", basically a radical mind (meaning deep thought, down to the roots) was okay, and actually thought it was supposed to be that way. Let's say, for example, that in his heart Indonesia is in a lot of trouble (economics, education, laws, and politics) because Indonesia does not implement Islamic strategy. And therefore, for example, the foundations of Indonesia must be replaced with the systems of Islamic government (khilāfah is revimiyyah). Such radical opinions are valid. ${ }^{8}$

\section{Good-Looking}

Good-looking is a lot of English words or phrases. In literature.id, good-looking can mean handsome, handsome, nice, handsome, fair, and pretty. From such meanings, good-looking provides reflective meanings that can mean as kindness, cleanliness, and neatness. If we understand the identification of such significance, good-looking might seem edible not only to a person's good looks, but also to the appearance or state of anything that is good, clean, and no dirt. For example, good-looking at mosques, good-looking at beds, good-looking in salat, and so on. ${ }^{9}$

In Indonesia the radicalism phenomenon is increasingly evident. In its analysis Sidney Jones has the number of minorities, and fewer than those who use violence. Greg Barton also added that religious radicalism occurred again in the decade of 1950, this buffet was marked by the advent of the Darul Islamic movement. But in 1962, DI/TII's movement can be broken by the Indonesian government, But the movement has already received sympathy and support from some muslims in Indonesia.

\section{Statement}

Statement is a sentence that has either true or false value but neither is true nor false. (statements are also called prepositions, declarative sentences). It is correct to agree between what is stated and what is true. Whereas according to the dictionary, the statement is an act of making public or making public declaration on a matter. ${ }^{10}$

The question of theoretical truth is simply a comparison between the reality of object (information, facts, events, opinions) and what the subject captured (ideas, impressions). If the idea or impression on the subject corresponds with reality, object, then something is correct. The theory of corespostation (independence theory of truth), explaining that truth or something of truthfulness, proves to be correct when there is a discrepancy between the meaning of a statement with the object to which it is intended or intended. Truth is a harmonious statement with fact, which corresponds with reality in harmony with the actual situation.

\section{The Country's Civilian Personnel}

The country's civilian personnel which would be abbreviated, is a profession for civil servants and government employees with employment agreements that work on government agencies. The civil personnel employees which are then referred to as civil servants and government employees, are usually referred to as employees of the government and are assigned to duties in a government office or are given other government duties and are paid according to regulations of the law. ${ }^{11}$

According to the law, the Indonesian government has met certain requirements and has been appointed a permanent servant to the government as a government official. At the same time, the number of people on the market was still small, he said. As for the staff building officials, it is

\footnotetext{
8 Syahrin Harahap, Upaya Kolektif Mencegah Radikalisme dan Terorisme (Jakarta: Siraja, 2017): 29.

9 Akurat.co, Refleksi Makna “Good Looking” dalam Pandangan Islam, accessed on September 82020. https://akurat.co/rahmah/id-1209369-read-refleksi-makna-ldquo-good-looking-rdquo-dalam-pandangan-islam 10 https://jagokata.com/arti-kata/pernyataan.html, Accessed on 23 September, 2020.

${ }^{11}$ http://repository.umy.ac.id/bitstream/handle/123456789/6834/f.\%20BAB\%20II.pdf?sequence=6\&is Allowed=y, Accessed on 23 September, 2020.
} 
an official who has the authority to enforce, appoint, transfer, and desist and manage civil apparatus management in government agencies in accordance with existing regulations of the law.

Civil apparatus management in government employees are appointed and assigned to a government office. According to Utrecht, office is a permanent sphere of work brought forth and performed for the benefit of the state. Forty-two offices are the subject of rights and obligations. Therefore, when one takes up an office, from it comes the right and obligation and ability to perform judicial works. However, the rupiah still had a chance to strengthen again, he said. This can be noted from the paragraph fourth of the opening of the constitution of the Republic of Indonesia

(UUDNRI) 1945 which mentions:

... then rather to form a government that protects the whole of Indonesia and all of Indonesia's homeland and to promote public welfare, enlighten the lives of the nation, and contribute to the administration of a world of perpetual peace and social justice...

\section{Methods}

The research is using a method of critical analysis of Teun A. van Dijk. Using descriptive qualitative research, describing an object, phenomenon, or social setting that will be presented in a narrative writing. ${ }^{12}$ Text analysis consists of a number of grade structures that each section supports one another. There are three degrees in text analysis: macro structure, superstructure, and micro structure. Then search out and classify the sentence and its meaning according to the three elements above.

\section{Results and Discussions}

\section{Text}

Analysis of the text in the Minister of Religion's statement on good-looking radicalism, researchers see either a good-looking radicalism sentence or a radical entry agent is through an attractive figure spoken by parliament to be a point of deep analysis. It's first look at the meaning of radicalism and good-looking as it has expressed before that radicalism is a thinking or attitude characterized by four things at once, namely: intolerance and not respecting others opinions or beliefs, bigotry, exclusive attitudes, and revolutionary attitudes. And good-looking is an attractive looking man. So, good-looking radicalism is what the radicalism is all about.

The following writer will describe the structure of the text contained in the statement of the Minister of Religious's Affairs:

The solid text structure in the Minister of Religion about good-looking radicalism.

\section{a. Macro Structure}

The macro structure analyzed is the text's global meaning that can be understood through the themes, topics and subtopics presented in the text. The topic could be shown in the title of the "radicalism counter strategy for civil personnel" online seminar was the theme raised in the weggement of the ministry of personnel manipulation and bureaucratic reform. From the theme above, we can see how strategies can be made to ward off radical inroads in the country's civil societies. It explains how radical innuentures in a country's civil personnel environment, one of which involves putting attractive people in places such as an institution of education and a house of worship. Then begin to affect communion with its belief.

\section{b. Superstructure}

The statement of the Minister of Religious Affairs in the webinars "radicalism strategy for civil personnel" begins with a talk about civil personnel radicalism. Then there are a lot of places to look out for first place he went in. If not carefully selected, the worries of the seeds or radical ideas

\footnotetext{
${ }^{12}$ Albi Anggito \& Johan Setiawan, Metodologi Penelitian Kualitatif, (Sukabumi: CV Jejak, 2018), 11.
} 
enter the civil personnel for example caliphate. The reference to the caliphate is not restricted to legislation, but such thoughts should not be accepted at civil personnel. That was part of the selection moment.

Radicalism is easily dispersed in any direction, but it is wise to be aware of some important places. Vulnerable places to be on the lookout for radicalism, where first in educational institutions there must be strict selections when receiving tutors, teachers, and others in order to avoid entry into and teach to the young generation of students or students.

The second through the state's civil personnel services, from houses of worship or places of worship, he explains that radical inroads of understanding are among other things from radical incomes to mosques or churches, etc., usually beginning with good-looking people, good Arabic and enough religious knowledge, which then after being accepted at the administration of religious services, began to spread radical teachings, then bring in the same spoilers of his friends. This is a national civil service emergency.

For example, a boy with a " good-looking" of Arabic mastery or hafiz, then a priest, then a sympathetic ward, so that he was appointed a clerk and from there came radical doctrinal ideas. In a glow the Minister of Religions made an agreement with Mr. Minister of the Ministry of personnel manipulation and bureaucratic to beware of places of worship in government institutions that the administration should be of government employees and they believe there will be no radicalism known.

It is the controversy in society, as some have responded to it:

1) Vice chairman of the Indonesian Council of Scholars Muhyiddin Junaidi.

The Indonesian council of scholars has asked the Minister to withdraw all these unconstitutional accusations because they hurt and hurt the feelings of muslims who had done much to free this country and fill freedom with real works. The statement simply pointed to the misapprehension of the Minister of religion and inaccurate data. It is as if only muslims and the huffaz al-Qur'an and people of various muslims. The Minister of Religious Affairs with military background should understand more about the role of Indonesian muslims and make it reference to creating national stability, unity and progress in the middle of inequality.

He pointed out that the Minister of Religious Affairs should not support those who have hidden agendas and should be more informed about the role of Indonesian muslims and refer to creating national stability, unity and progress in the middle of single development. There should not be a single case found in society as the behavior of the majority of muslims. Since he became the Minister of the Clergy to take the fall, he is muslims. Never alludes to other religious followers who do the damage, even using a place of worship as a means of undermining the undisputed generations of anti-state the Republic of Indonesia and separatists of radicalism, the common enemy and removing all its negative stigma on muslims who joined bad for righteousness and justice in the Indonesian state. ${ }^{13}$

2) General Director of Community Guidance (Bimas) Kamaruddin Amin

Good-looking's statement was merely an illustration. According to Fachrul Minister of Religion, the need for careful care of house administrations, especially those within the government and state-owned enterprises, in order to understand the records of his congregation's religious views. ${ }^{14}$

\section{c. Micro Structure}

\footnotetext{
13 Kanavino Ahmad Rizqo, Agen Radikalisme 'Good Looking' Tuai Polemik, Menag Beri Penjelasan, DetikNews, accessed on October 08, 2020, https://news.detik.com/berita/d-5161955/agen-radikalisme-goodlooking-tuai-polemik-menag-beri-penjelasan.

14 Dicky Aditya, Heboh Soal Good Looking di Media Sosial, Dirjen Binmas Berupaya Luruskan Maksud Menag, GalamediaNews.com, accessed on October 24 2020, https://galamedia.pikiran-rakyat.com/news/pr35719327/heboh-soal-good-looking-di-media-sosial-dirjen-binmas-berupaya-luruskan-maksud-menag.
} 
The selection of the word "good-looking radicalism" in the statement of Minister of Religious Affairs was part of the deconstructing ideology that the Minister wanted to convey. In this case, too, there is a rampart of disapproving and opposing as this character is overcome:

1) Executive Director of the Nusantara Cultural and Religious Studies Circle Fadhli Harahab

Fadhli Harahap confirms Fachrul Razi's statement that of course put Islam in a very compromising position, especially the Qur'an. It's as if memorizing the Qur'an is radical. Let's not get one or two cases, and then let's all be accounted for. He said, "It's flawed logically."

2) Chief PBNU Marsyuhdi Shuhud (Former Vice Chief of Indonesian State Army)

Claiming that radicalism can enter from any door, such as web sites, Internet, reading books, friendships will include, coming from everywhere, such views and beliefs. Whether they are radicalized by an attractive figure or good-looking and have a good religion he thinks is an experience obtained by the Minister of Religion, but the true sense of it can come from anywhere. Fachrul statement on the webinars basically reminds people to stay alert. If understanding is compromised, citizens are asked to report immediately. So those words are an expression of prudence.

\section{3) According to Haidar Alwi as an Anti-Radicalism Member}

There are three kinds of radicalism; the creeds in which every day predominate everyone except his own group. The second is an action radical that always does the same thing for the ansharut daulah group. The third is radical in a political form, in this radical case a group that wishes to replace the country's legitimate ideology of Pancasila with the ideology of the caliphate.

\section{Social Cognition}

The narrative analysis not only limits its attention to the structure of the text but also how the text is produced. Van Dijk's social cognition of the theory of Van Dijk is described by identifying the form of knowledge or the k-device (form of the knowledge study strategy in interactions) used in the discourse. ${ }^{16}$

\section{Social Contexts}

Discourse analysis not only limited social analysis (social context) to things that affect language usage, and a discourse is created. This context also relates to who or who in communication relationships. Who is the communicator, who is the communican, in what circumstances, what the medium is, and why the event exists. In this social analysis research the developing discourse in the community. How societies produce and project a discourse on the structure of the text, but also how the text is produced. ${ }^{17}$

Identifying characteristics of the rope of social networks is the frequency of contact with the rope of social networks, the source of the rope of social networks and the quality of contact. These three characteristics of social networks are positively associated with good elderly self-health, stimulating and mental health of the elderly. There is evidence that the quantity and quality of social network contact affect health. Satisfaction with or with social contact becomes more important to the elderly in relation to their aged health status than their social frequency. Melchior, suggested that complacency in social relationships is the best predictor of health achievement compared to the measurement of structural social networks. According to contact sources, it has been found that the frequency of social contact with neighbors is strongly associated with the achievement of good health compared with the frequency of contact with friends and family.

The positive effects of social relationships and other social networks are also known from some research reports showing that a person with an age and a large network of active social

\footnotetext{
15 Rakhmatullah, Sebut Good Looking-Khafiz Sebar Radikalisme, Menag dinilai Sesat Nalar, SindoNews, accessed on October 24 2020, https://nasional.sindonews.com/read/155620/15/sebut-good-lookinghafiz-sebar-radikalisme-menag-dinilai-sesat-nalar-1599350948.

${ }^{16}$ Eriyanto, Analisis Wacana Pengantar Analisis Teks Media (Yogyakarta: LKiS Yogyakarta, 2015), 259.

17 Ibid., 272-273.
} 
relationships tend to be happy in life (Phillips, 1967; Burt, 1987). Old age may have suffered a reduction in social networks because of the death of family and friends. Social relationships, where involvement in society, are also closely linked to health and well-being. Providing help and involvement in political or charitable organizations and doing volunteer work will strengthen the structure of civil society and be thought of as promoting social capital and cohesion.

The practice of Van Dijk's power defines that power as belonging to a group (or its members), one group to control the group (or members) of another group. This power is based largely on possession of valuable resources such as money, status, and knowledge. Beyond direct and physical control, power is also persuasive.

In the study that became a communicator, the Minister of Religion was a messenger how to counteract the agents of radicalism by carefully selecting the country's civilian personnel. The minister of Religion as a character of many people, thus able to persuade the public to stay alert to radicalism especially with attractive persons.

The relationship between power and knowledge became a central theme in all of Foucault's studies throughout his intellectual career. Yet, of all his works, Foucault rarely actually explains the connection between power and knowledge. Several writings and interviews with Foucault assembled in a book power or knowledge sought to demonstrate an explicit relation to power and knowledge. However, both through his interviews and his writing and his lecture, There was no specific discussion of the relation between power and knowledge other than the thematic conclusion of the book editor. The problem is, in the end, difficult to understand the relationship of power and knowledge, even though Foucault has actually also shown the relationship in his early works. According to him, what else is spoken of in subjects such as insanity, discipline, and other sexuality as operating on a framework between power and knowledge.

Foucault is more intense about power thematic than it is about knowledge. Therefore, in this section, the theme of the relationship between power and knowledge will be discussed in contrast to Foucault's conception of power.

\section{a. Access Affects Discourse}

The discourse analysis of Van Dijk's theory pays great attention to the eins and outs, as among other groups in society. A group of rulers had greater access to power than the common group. Therefore, those with greater power have a greater opportunity to influence public awareness. Greater access not only provides an opportunity to control greater public consciousness, but also determines what topics and contents of the discourse can be spread and discussed to the people.

A powerful person has a privilege or a value or a plus in a society, as with the Ministry of Religious Affairs, what he says can affect public consciousness, is because governments have a strong hierarchical power to control and control society by using the laws and regulations established on both a central and an area scale. According to Sujiwo Tedjo the access or influence of not only comes from rulers, the culture says that public figures and figures also play a very special role in moving and controlling society by traditional rules and religious and fashion that are fashionable in society.

The context that takes place in such a situation is an indication in the community of people who believe that everyone in a robe with a turban on his head is an ustadh or teacher or religious leader to be an example of all the life style he used. And the fact that many of the religions leaders who daily exemplify evil in both word and deed, there are even some who openly want to give their followers radicalism in order to oppose them and to be the most truthful person in state and religious order. And here is the role of the government that should be the bastion of the understanding. 


\section{E. Conclusion}

A sparkle attended by government parliaments particularly the Minister of Religious Affairs videos gleams about "Radicalism strategies in civil personnel." Fachrul Razi takes the whole of the country's civil personnel and all elements of government to come together to build a good government, the good news is that it is up to the point of launching a radical state civillian personnel application and a happy announcement in commemorating the 75th year in Jakarta. In a program that deals with counter-radicalism strategies for civil apparatus, also reminding the importance of a Shared understanding of religious moderation. The society's leaders have been sequestered, constantly reminding its followers of religious moderation.

The society's leaders have been sequestered, constantly reminding its followers of religious moderation. The invitational guest: Minister of PAN-RB Thjahjo Kumolo, Chief of BNPT Boy Rafli Amar, Chief of BKN Bima Haria Wibisana, and Gumilar R. Somantri the academic, official Eselon I dan II KEMENPANRB. Present Minister of PAN-RB Thjahjo Kumolo, chief of BNPT Boy Rafli Amar, chief of BKN Bima Haria Wibisana, and Gumilar R. Somantri, official of Eselon I dan II Kemenpan $\mathrm{RB}$, And the local community officers who were present through the sparklers.

Through the theory of analysis of the van Dijk model, the analysis reveals a sentence of macrostructure on the statement is a strategy that can be devised to counter the radical incomes of state civil apparatus. It explains how a radical admission in a country's civil personnel environment is one of which involves putting someone in an attractive appearance. For and against the growing appeal of the Minister of Religion, especially from various social leaders such as General Vice President of MUI, the Minister said the need for discretion. The Executive Director of the Nusantara Cultural and Religious Studies Circle Fadhli Harahab, Chief PBNU Marsudi Syuhud (a former deputy chief of the Indonesian army) responded that these words were an expression of caution, Haidar Alwi as an anti-radicalism worker calling three different forms of radicalism.

The case above has shown that a lot of ocnum ustadh who clearly pointed his words had insulted others with harsh language. Human science is not justified because it has been radically insulting to someone. The aim of the Minister of Religious Affairs in his declaration to invite all civil personnel to be aware of radicalism or radicalism in various ways by bringing in an entire government parliament for the state of Indonesia.

\section{References}

Aditya, Dicky. "Heboh Soal good-looking di Media Sosial, Dirjen Binmas Berupaya Luruskan Maksud Menag". GalamediaNews.com. Accessed on October 24 2020, https://galamedia.pikiran-rakyat.com/news/pr-35719327/heboh-soal-good-looking-dimedia-sosial-dirjen-binmas-berupaya-luruskan-maksud-menag

Akurat.co, "Refleksi Makna " good-looking" dalam Pandangan Islam". Accessed on September 8 2020. https://akurat.co/rahmah/id-1209369-read-refleksi-makna-ldquo-good-lookingrdquo-dalam-pandangan-islam

Anggito, Albi \& Setiawan, Johan. Metodologi Penelitian Kualitatif. Sukabumi: CV Jejak. 2018.

Eriyanto. Analisis Wacana Pengantar Analisis Teks Media. Yogyakarta: LKiS, 2015.

Harahap, Syahrin. Upaya Kolektif Mencegah Radikalisme dan Terorisme. Jakarta: Siraja, 2017.

Kusmanto, Thohir Yuli, Fauzi, Moh. Jamil, M. Mukhsin. "Dialektika Radikalisme Dan Anti Radikalisme di Pesantren. "Jurnal Walisongo" 23, no .1 (2015): 27-50. https://journal.walisongo.ac.id/index.php/walisongo/article/view/221/202.

Musyafa'ah, Nurul. "Analisis Wacana Kritis Model Teun A. Van Djik (Siswa Berprestasi jadi Pembunuh) “. Jurnal Program studi PGMI 4, no. 2, (2017): 204-211.

Qadhawi, Yusuf. Islam Radikal. Solo: PT Era Adicitra Intermedia. 2007. 
Vol. 2 No. 1, 2020

Rakhmatullah, "Sebut good-looking-Khafiz Sebar Radikalisme, Menag dinilai Sesat Nalar",

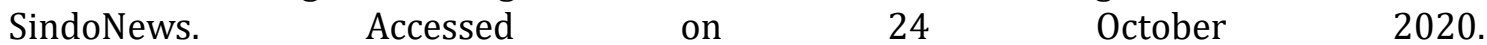
https://nasional.sindonews.com/read/155620/15/sebut-good-looking-hafiz-sebarradikalisme-menag-dinilai-sesat-nalar-1599350948

Rizqo, Kanavino Ahmad. "Penjelasan dan Kontroversi Agen Radikalisme good-looking”, DetikNews. Accessed on October 08 2020. https://news.detik.com/berita/d-5162351/penjelasan-dankontroversi-agen-radikalisme-good-looking/1

Sholeh, Muhammad Khomsun. Menangkal Masuknya Paham Radikalisme Pada Masyarakat Desa. Temanggung: Desa Pustaka Indonesia, 2019.

Smart Blog Mathematics. "Pernyataan dan Bukan Pernyataan". Accessed on October 152020 dari https://smartblogmathematic.wordpress.com/pernyataan-dan-bukanpernyataan/\#: :text=Pernyataan\%20adalah\%20kalimat\%20yang\%20mempunyai,dinyat akan\%20dengan\%20keadaan\%20yang\%20sebenarnya.

http://repository.umy.ac.id/bitstream/handle/123456789/6834/f.\%20BAB\%20II.pdf?sequenc e=6\&isAllowed=y. Accessed on 23 September, 2020.

https://jagokata.com/arti-kata/pernyataan.html. Accessed on September 23, 2020. 